\title{
The Association between Gadget Addiction and Myopia in the Medical Student of Universitas Prima Indonesia
}

\author{
Andre Budi*, Chrismis Novalinda Ginting*, Linda Chiuman*, Ermi Girsang** \\ ${ }^{*}$ Faculty of Medicine, Universitas Prima Indonesia, Medan, Indonesia \\ ** Faculty of Public Health, Universitas Prima Indonesia, Medan, Indonesia \\ DOI: 10.29322/IJSRP.12.01.2022.p12108 \\ http://dx.doi.org/10.29322/IJSRP.12.01.2022.p12109
}

\begin{abstract}
The high prevalence of myopia in some countries in Asia include Indonesia. There are several risk factors for myopia. One of them is gadget usage. This study was aimed to explore the effect of gadget addiction among Medical students, especially in the Medicine Faculty of Prima Indonesia University. This study was an observational study with Case Study Control Design in Faculty of Medicine, Prima Indonesia University, Medan. The population was all student that was registered as the student of the faculty of Medicine, Prima Indonesia University, and the sample was gotten by disproportional stratified random sampling. The data was obtained from the study include the characteristic of the participants and risk factors for myopia. The result of this study showed that the gadget addiction was a risk factor for myopia based on bivariate analysis (OR: 2.919, 95\% CI: 1.541-44.792). However, the gadget addiction was not a risk factor for myopia based on multivariate analysis (OR: 2.919, 95\% CI: 0.312-27.287). Hence, gadget addiction partially affected myopia.
\end{abstract}

Index Terms- Gadget addiction, Myopia, Medicine Faculty, Student

\section{INTRODUCTION}

Myopia or nearsighted is a condition when the image of distant objects focus in front of the retina in the unaccommodated eyes. There are two types of myopia include axial and refractive myopia. The refractive myopia was due to the refractive elements were more refractive than average, while axial myopia occurred due to the eye is longer than average [1]. Based on the spherical equivalence (SE), myopia and high myopia is ranged from -0.50 diopters or less and -5.00 diopters or -6.00 diopters, respectively [2].

Myopia affected around 27\% (1893 million) people over the world in 2010, and in the small number that is approximately 2.8\% (170 million), people have high myopia. The highest prevalence of myopia was found among East Asia, China, Japan, the Republic of Korea, and Singapore that account for around 50\% and lower prevalence in Australia, Europe, North, and South America. Based on the estimation of the United Nations Data, the prevalence of myopia will be increased gradually from 2000 to 2050 that can reach 52\% (4949 million) person in 2050 [3], [4].

On the other hand, the data for the prevalence of myopia is not available yet. The Indonesian health of ministry only reported the prevalence of low vision. The prevalence of severe low vision among $<6$ years old person is $0.9 \%$ nationally. The highest prevalence of myopia was found in the Lampung around $1.7 \%$, followed by the Nusa Tenggara Timur and Kalimantan Barat that were $1.6 \%$ and as the opposite, the lowest prevalence of severe low vision was found in the DI Yogyakarta $(0.3 \%)$ followed by Papua Barat and Papua that were $0.4 \%$ [5]

There are various risk factors for myopia. Wulansari et al. (2018) reported the last knowledge of parents, economic state, distance reading book, and outdoor activity on the weekend. Interestingly, Wulansari et al. also reported that the prevalence of myopia was significantly higher in the urban population than the suburban population [6]. Furthermore, Primadiani and Fifin (2017) reported that the Medical Student also at high risk to suffer from myopia. There were several factor significant risk factors of myopia includes Family history of myopia, distance, time, position, and light intensity on the activity of close-range vision [7]. Meanwhile, Wahyuningrum and Prameswari (2018) reported that gadget addiction was a correlation with the visual acuity among Elementary School students in Mlirip II Mojokerto [8].

A gadget is a small tool that has a particular function. The usage of the gadget cannot be avoided from the human life that has been the firm hold on addiction to children and adults as well. On the other hand, the gadget also has several disadvantages in some areas like health, public safety, and education. Furthermore, the gadget can affect the health of some organs and even affecting eyes [9]. Due to the high impact of the gadget on the health area, this study was aimed to explore the effect of gadget addiction among the Medical Student, especially in the Medicine Faculty of Prima Indonesia University, as the high-risk population. 


\section{METHODS}

This study was an observational study with Case Study Control Design in Faculty of Medicine, Prima Indonesia University, Medan. This study has been approved by Health Research Ethics Committee from Universitas Prima Indonesia with registration no. 014/KEPK/UNPRI/IX/2019.

The target population of this study was all student that was registered as the student of the faculty of Medicine, Prima Indonesia University during this study was conducted (March 2019- May 2019). The following formulation determined the number of this sample:

$$
\mathrm{n}=\frac{\mathrm{Za}^{2} \mathrm{x}(\mathrm{pq})}{\mathrm{d}^{2}}
$$

Based on the formulation, the minimal number of samples was 14 participants to represent $95 \%$ of the target population. The sample of this study was gotten by disproportional stratified random sampling that was 10 participants from each year of entry. The case group was the participants that confirmed to has myopia by the Snellen chart. Furthermore, the case group was to determine the spherical power of the eye by the trial and error set lens. Meanwhile, the control group was the participants that confirmed to has no myopia by the Snellen chart. The participant that has anisometropia was excluded from the sample.

The data was obtained from the study include characteristic of the participants (Age, Sex, and Spherical Power) and risk factors (Parenteral Myopic History, Interval of Rest The Eyes for 5 minutes, and gadget addiction) was analyzed descriptively. Furthermore, the analysis was followed by the chi-square as the bivariate and logistic regression as the multivariate.

It's the foremost preliminary step for proceeding with any research work writing. While doing this go through a complete thought process of your Journal subject and research for it's viability by following means:

1) Read already published work in the same field.

2) Goggling on the topic of your research work.

3) Attend conferences, workshops and symposiums on the same fields or on related counterparts.

4) Understand the scientific terms and jargon related to your research work.

\section{RESULTS}

The result of this study showed that there are 29 participants that suffer from myopia and remain of participants were grouped as the control. The characteristic of the participants was revealed by the following table.

Table I: Characteristic of Participant

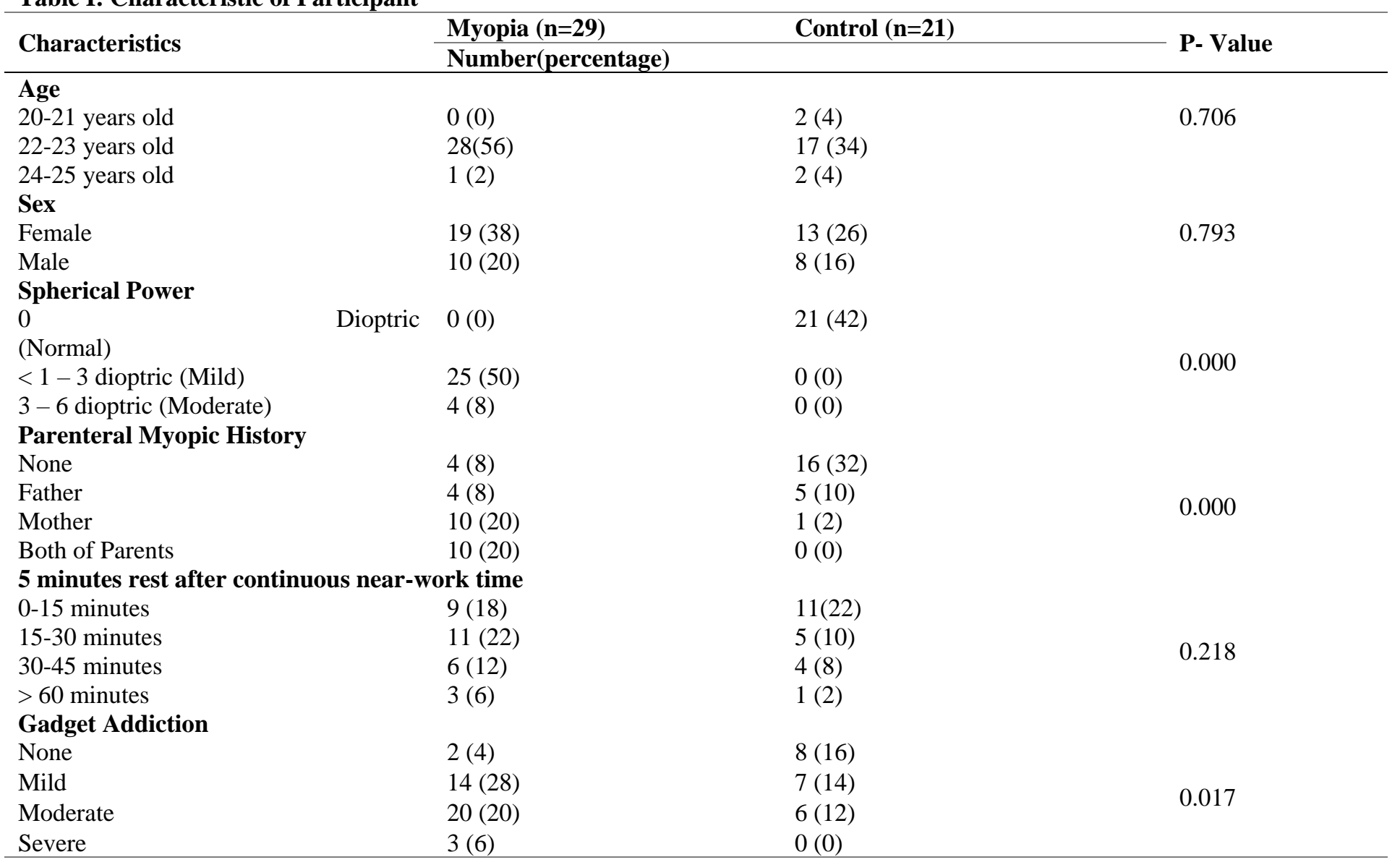


Based on the table I, most of the participants that suffer from myopia were aged 22-23 years old (56\%), and most of the participants were female (38\%). On the other hand, the result of the trial and error lens examination among the case group showed the most participants had the spherical power range from $<1-3$ dioptric $(50 \%)$. Furthermore, the risk factor that significantly affected the myopia was paternal myopic $(\mathrm{P}-\mathrm{Value}=0.000)$ and gadget addiction $(\mathrm{P}-\mathrm{Value}=0.017)$. The most of parenteral myopic history in the case group was the mother (20\%), and both parents (20\%), while most of the participants in the case group have the severity of gadget addiction was moderate $(20 \%)$.

This result of the study was supported by Sun et al. (2018), who reported that Parental myopia (P-Value $<0.05)$ and 5 minutes rest after continuous near-work time (P-Value < 0.05) also a risk factor of myopia by the bivariate analysis $($ Chi-Square) [10]. Furthermore, this analysis was followed by the chi-square and regression logistic, and the following table showed the result of the analysis.

Tabel II: Association of Myopia with Gadget Addiction

\begin{tabular}{|c|c|c|c|c|c|c|}
\hline Gadget & Bivariate & & & Multivariate* & & \\
\hline Addiction & OR & $95 \% \mathrm{CI}$ & P-Value & OR & $95 \% \mathrm{CI}$ & P-Value \\
\hline$\frac{\text { Not Yet }}{\text { Addicted }}$ & 8.308 & $1.541-44.792$ & 0.017 & 2.919 & $0.312-27.287$ & 0.347 \\
\hline
\end{tabular}

*Odds Ratio (OR) was adjusted for sex, age, Parenteral Myopic History, and Interval of Rest the Eyes for 5 minutes

Based on the table above, the gadget addiction was the risk factor of myopia, according to the bivariate analysis. However, in the multivariate analysis, the effect of gadget addiction as the risk factor was not significant. The bivariate analysis showed that OR was 8.308 , which meant the participants that had 8.308 times to suffer from myopia than the control group. Furthermore, the analysis was followed by the multivariate by adjusting the model with Sex, age, Parenteral Myopic History, and Interval of Rest the Eyes for 5 minutes and the gadget addiction was not significantly become the risk factor for suffering from myopia due to the P-Value of the Multivariate analysis was lower than 0.05 .

\section{DISCUSSION}

The result of this study has answered the purpose of this study. The gadget addiction individually affects the prevalence of myopia among the medical student, but other factors like sex, age, Parenteral Myopic History, and Interval of Rest the Eyes for 5 minutes affect the association between the gadget addiction and prevalence of myopia.

Wahyuningrum and Prameswari (2018) reported a similar result that the frequency and duration of gadget correlated negatively with visual acuity. The increase of the duration and frequency usage of gadgets decreases the visual acuity ratio by 5.299 and 5.986 times, respectively. The level of the model of correlation was $85.3 \%$ [8].

There is another study that reported the opposite result. Puspa et al. (2017) reported that the usage of the gadget was not significantly acted as the risk factor for myopia $(\mathrm{P}-\mathrm{Value}=0.966)$. However, the usage of gadgets significantly caused dry eyes syndrome $(\mathrm{P}-$ Value $=0.042)[12]$.

Technological development has increased rapidly, especially the electronic device due to the presence of the internet network that has been changed the mode of communication, education, and entertainment. There are several advantages of this development includes facilitating access to information, communication with friends, networking on social media, and entertainment. On the other hand, this development also induces new pathologies due to the excessive usage of internet network on gadget [11].

The gadget can produce High-Energy Visible (HEV) or blue or violet light that can penetrate the macular pigment and cause more rapid retinal changes. These changes lead to structural damage to retinal and also reduce visual acuity. The wavelength, frequency, and exposure time affect this damage severity. Some gadgets also produce UV rays that can increase the risk of cataracts, AMD, and other eye disorders [9].

\section{CONCLUSION}

Gadget addiction was the risk factor of myopia separately. However, it did not simultaneously act as a risk factor of myopia.

\section{ACKNOWLEDGMENT}

The preferred spelling of the word "acknowledgment" in American English is without an "e" after the "g." Use the singular heading even if you have many acknowledgments.

\section{REFERENCES}

[1] P. Riordan-Eva, 'Optik \& Refraksi', in Vaughan \& Asbury 's General Opthalmology, 17th ed., P. Riordan-Eva and J. P. Whitcher, Eds. EGC, 2010, pp. 382-398.

[2] M. Ang and T. Y. Wong, Updates on Myopia (A Clinical Perspective). Singapore: Updates on Myopia, 2020.

[3] WHO, The Impact of Myopia and High Myopia, no. March. Sydney: World Health Organization-Brien Holden Vision Institute, 2015. 
[4] B. A. Holden et al., 'Global Prevalence of Myopia and High Myopia and Temporal Trends from 2000 through 2050 ', Ophthalmology, vol. 123, no. 5, pp. 1036-1042, 2016.

[5] Badan Penelitian Dan Pengembangan Kesehatan Kementerian Kesehatan RI, 'Riset Kesehatan Dasar 2013 ', 2013.

[6] D. Wulansari, F. L. Rahmi, and T. Nugroho, 'Faktor-Faktor Yang Berhubungan Dengan Miopia Pada Anak Sd Di Daerah Perkotaan Dan Daerah Pinggiran Kota', J. Kedokt. Diponegoro, vol. 7, no. 2, pp. 947-961, 2018.

[7] I. S. Primadiani and F. L. Rahmi, 'Faktor-Faktor Yang Mempengaruhi Progresivitas Miopia Pada Mahasiswa Kedokteran', J. Kedokt. Diponegoro, vol. 6, no. 4, pp. 1505-1517, 2017.

[8] T. Wahyuningrum and V. E. Prameswari, 'The Relationship between Gadget Addiction and Visual Acuity in Elementary School Student of Mlirip II Mojokerto', Int. J. Nurs. Midwifery Sci., vol. 2, no. 3, pp. 217-221, 2018.

[9] N. Kumar and M. Amarnath, 'A Review on Effects of Electronic Gadgets on Eye.', J. Ayurveda Physicians Surg., vol. 5, no. $1,2018$.

[10] J. T. Sun, M. An, X. B. Yan, G. H. Li, and D. B. Wang, 'Prevalence and Related Factors for Myopia in School-Aged Children in Qingdao', J. Ophtalmol., vol. 2018, pp. 1-6, 2018.

[11] K. S. Kurniasanti, P. Assandi, R. I. Ismail, M. W. S. Nasrun, and T. Wiguna, 'Internet addiction: A new addiction?', Med. J. Indones., vol. 28, no. 1, pp. 82-91, 2019.

[12] A. K. Puspa, R. Loebis, and D. Nuswantoro, 'Pengaruh Penggunaan Gadget terhadap Penurunan Kualitas Penglihatan Siswa Sekolah Dasar', Glob. Med. Heal. Commun., vol. 6, no. 1, pp. 28-33, 2018.

\section{AUTHORS}

Andre Budi - Faculty of Medicine, Universitas Prima Indonesia, Medan, Indonesia.

Chrismis Novalinda Ginting - Faculty of Medicine, Universitas Prima Indonesia, Medan, Indonesia.

Linca Chiuman - Faculty of Medicine, Universitas Prima Indonesia, Medan, Indonesia.

Ermi Girsang - Faculty of Public Health, Universitas Prima Indonesia, Medan, Indonesia.

Correspondence Author - Andre Budi, andre87budi@hotmail.com. 